\title{
Izgubljeni prihodi i pronađena solidarnost: utjecaj prvog vala pandemije bolesti COVID-19 na kulturni sektor u jugoistočnoj Europi
}

\author{
Jaka Primorac \\ Institut za razvoj i međunarodne odnose, Zagreb, Hrvatska \\ e-mail: jaka@irmo.hr
}

SAŽETAK U radu se donose rezultati istraživanja o utjecaju prvog vala pandemije bolesti COVID-19 na život i rad kulturnih radnika i radnica u jugoistočnoj Europi provedenog od svibnja do srpnja 2020. godine. Rad ukazuje na to kako je u navedenom razdoblju u svim istraživanim zemljama (Bosna i Hercegovina, Crna Gora, Hrvatska, Sjeverna Makedonija, Slovenija i Srbija) kod ispitanika/ica uslijed nemogućnosti rada zabilježen značajan pad prihoda, predviđen je pad ukupnih primanja te nastavljen trend nužnosti dodatnih poslova i samoeksploatacijskih praksi. U istraživanim zemljama mjere za smanjenje negativnih posljedica pandemije na kulturni sektor uglavnom nisu donesene na lokalnoj razini, a ukoliko su donesene na nacionalnoj razini, uključivale su pretežno jednokratnu pomoć umjetnicima/ama i kulturnim radnicima/ ama te odabrane mjere posrednog tipa, pri čemu je prisutna razlika između zemalja članica EU-a i onih koje to nisu. Podaci pokazuju ograničen utjecaj međunarodnih zaklada i mreža na sektor, ali se zato diljem regije pojavio niz inicijativa i mreža solidarnosti profesionalnih udruženja, NVO-a te nezavisnih kulturnih radnika i radnica. Podaci pokazuju da je i za kulturni sektor u jugoistočnoj Europi prvi val pandemije bolesti COVID-19 donio niz negativnih posljedica, dok su rane policy mjere u većini zemalja bile ograničenog utjecaja i opsega. Pozitivni učinci očituju se u osnaživanju solidarnosti unutar sektora i većem umrežavanju kulturnih radnika i radnica te jačanju vidljivosti da je potreban novi održiviji pristup kulturnom sektoru a koji se ne temelji na tržišnoj logici.

Ključne riječi: kulturni sektor, COVID-19, pandemija, kulturni rad, projektni rad, kulturne politike, jugoistočna Europa, otpornost. 


\section{Uvod ${ }^{1}$}

Unutar posljednjih petnaestak godina kako na europskoj tako i na svjetskoj razini objavljen je niz istraživačkih radova te policy studija o nesigurnoj i ranjivoj poziciji umjetnika i umjetnica te kulturnih radnika i radnica. Radna fragilnost u kulturnom sektoru prvenstveno se povezuje uz projektni fleksibilni tip rada ( $r a d$ na određeno i povremeni rad), koji je prema nizu pokazatelja u ovom sektoru učestaliji nego u drugim djelatnostima (Hesmondhalgh, 2002.; Ross, 2008.). Tako je i prema podacima o samozaposlenosti na europskoj razini za 2017. godinu koje nam pruža Eurostat (2018.) vidljivo da podaci o samozaposlenosti u kulturnom sektoru daju najveće kontraste u usporedbi s podacima o ukupnoj zaposlenosti. Dakle, na europskoj je razini u području umjetnosti i kulture udio samozaposlenih bio dvostruko veći nego u ukupnoj zaposlenosti, pri čemu je prisutna razlika između zemalja članica EU-a ${ }^{2}$. Ujedno, valja istaknuti da se radi o sektoru u kojem dominiraju mikropoduzeća, gdje je pretežno zaposlena visokoobrazovana radna snaga, te sektoru koji također karakterizira i visoki udio obavljanja dodatnih poslova (Hesmondhalgh, 2002.; KEA, 2006.). Za adekvatno funkcioniranje kulturnog sektora također je vrlo važan doprinos volonterskog rada kao jednog od oblika neplaćenog rada, a koji je posebice značajan za ulazak u rad u sektoru (McRobbie, 2002.; Ross, 2008.).

Podaci istraživanja provedenih u Hrvatskoj kao i u regiji jugoistočne Europe ukazuju također na prekarnu poziciju radnika i radnica u kulturnom sektoru. Također smještaju njegovo radništvo u posttranzicijski i postsocijalistički okvir dodatne strukturne nesigurnosti i zanemarenosti u javnopolitičkom odlučivanju (Barada, 2012.; Primorac, 2010.). Navedeni fragmentarni podaci za Hrvatsku ukazuju na veliku razliku između stalno zaposlenih u ustanovama u kulturi te na fragilnu poziciju (pretežno) projektno zaposlenih u kulturnim i kreativnim industrijama (Primorac, 2010.; Rašić i sur., 2015.) i još nesigurniji položaj zaposlenih u organizacijama civilnog društva u području suvremene umjetnosti i kulture (Barada i sur., 2016.). Važno je reći da se uvjeti rada u kulturnom sektoru razlikuju od područja do područja, kako u smislu djelatnosti koje se obavljaju (rad na filmu od npr. rada u muzejskoj djelatnosti) tako i prema sektoru. Pri tome je relevantno istaknuti da je velika sigurnost rada u sektoru ustanova u kulturi kontrastirana projektno orijentiranim sektorima kulturnih industrija te sektorima organizacija civilnog društva u području kulture i umjetnosti, u kojima dominiraju atipični oblici fleksibilne nesigurne zaposlenosti. Naravno, slobodni umjetnici i umjetnice tu stvaraju posebnu „lebdeću“ kategoriju koja surađuje na ugovornoj bazi kao samostalni djelatnici u svim navedenim podsektorima.

${ }^{1}$ Zahvaljujem se kolegama dr. sc. Predragu Cvetičaninu i dr. sc. Goranu Tomki na pomoći pri obradi podataka istraživanja.

${ }^{2}$ U nekim zemljama poput Njemačke udio samozaposlenih u kulturi iznosi $33 \%$ naspram 10\% u ukupnoj zaposlenosti, dok u Hrvatskoj nije prisutan takav drastičan kontrast. Samozaposlenost u kulturi nešto je niža od $20 \%$, dok samozaposlenost u ukupnoj zaposlenosti tek prelazi $15 \%$, pri čemu su podaci za zaposlenost u kulturi u Hrvatskoj niske pouzdanosti (Eurostat, 2018.). 
Upravo u vrijeme kada su, dakle, brojna istraživanja o radu u kulturnom i kreativnom sektoru ukazivala na sve veću nesigurnost, zatim na (samo)eksploataciju radnika i radnica te sve teži položaj umjetnika i umjetnica, na policy je razini i dalje bio dominantan neoliberalni diskurs o rastu kulturnih i kreativnih industrija i važnosti njihova udjela kako u BDP-u tako i u broju zaposlenih (KEA, 2006.). Štoviše, upravo je fleksibilnost projektnog tipa rada, koja karakterizira rad u sektoru, bila naglašavana kao primjer koji treba slijediti u ostalim područjima. I javne kulturne institucije koje su većinom bile u zavjetrini (premda niskog) javnog financiranja sve više su se našle pod pritiskom tržišnog diskursa pod egidom „kreativnosti“, gdje se opcija dodatnog projektnog financiranja potom pretvorila u nuždu. Dakle, provuklo se očište o razmatranju kulture samo kroz princip (neograničenog) ekonomskog rasta, razvoj kreativnosti kroz doprinos „talentiranih individua“, a koji je sve više udaljavao kulturu od društvenosti. Sam početak takvog razmišljanja može se pripisati programima i strateškim dokumentima razvijanim u Velikoj Britaniji krajem osamdesetih i devedesetih godina prošloga stoljeća (DCMS, 2003.; Myerscough, 1988.), koji su se potom proširili svijetom (UNCTAD, 2008.; UNESCO, 2013.). U to vrijeme mnogi su kako istraživači, stručnjakinje tako i obnašatelji javnih politika prihvatili stavljanje kulture u ekonomski fokus; s jedne strane kako bi koristeći različite ekonomske indikatore nadišli njen dotadašnji marginalizirani položaj, dok je $s$ druge strane bilo bitno da se napokon počne govoriti o tome kako se kultura proizvodi, kakav sve rad (umjetnika, kulturnih radnika/ica) stoji iza procesa proizvodnje i distribucije simboličkih dobara. Međutim, počevši od globalne krize 2007. i 2008. godine niz autora i autorica počeo je ukazivati na neke od problema koje donosi razmatranje kulture kroz isključivo tržišni pristup i ekonomski rast, kao što su: gentrifikacija, porast (samo)izrabljivanja i prekarnosti kulturnih radnika/ica, rastuće nejednakosti u sektoru, smanjivanje razine javnog financiranja kulture te sve veće dominacije monopolnih digitalnih posrednika poput Googlea i Facebooka na područje kulture i medija i njegovu platformizaciju.

Globalna kriza uzrokovana pandemijom bolesti COVID-19 stubokom je izmijenila kulturni sektor diljem svijeta. Već u prvom valu pandemije otkazani su koncerti, festivali, promocije knjiga, kazališne i plesne predstave, recitali, zatvoreni su muzeji, kina, klubovi i galerije, zaustavljena su snimanja filmova, albuma te su otkazivane probe, što je u vrlo kratkom vremenu dovelo do globalnog zastoja u kulturnoj i medijskoj proizvodnji. Upravo zbog dominantno projektnog pristupa radu u sektoru brojni su se kazalištarci, glazbeni umjetnici, likovne umjetnice, spisateljice, multimedijalni umjetnici, montažeri, tonci, prevoditeljice, lektori i galerijski vodiči našli kako bez posla tako i bez mogućnosti rada (jer rad od kuće za mnoge od njih zbog tipa posla nije opcija). Na globalnoj razini pokrenute su diskusije o nužnosti razvoja mjera za sektor ${ }^{3}$, ali su se

3 Ovdje se može istaknuti i globalna uloga UNESCO-a i tzv. pokreta ResiliArt (ResiliArt Movement), koji je iniciran od UNESCO-a na samom početku globalne krize uzrokovane bolešću COVID-19. Više o samom pokretu na: https://en.unesco.org/creativity/activities/resiliart. 
također počele pomalo sramežljivo javljati i ideje o nužnosti drugačijeg razmišljanja o kulturnom sektoru, financiranju kulture te posljedično i sveukupnom značenju kulture za društvo u cjelini. Štoviše, kako naglašavaju Mark Banks i Justin O’Connor: „kultura se sve više (ponovno) uspostavlja kao javno dobro a ne kao apstraktna 'industrija'. Ona kao i ostale javne usluge kao što su zdravstvo ili obrazovanje može biti shvaćena kao ekonomija, ali takva da joj je primarna svrha odgovoriti na društvene potrebe kao i na potrošačke prioritete“ (Banks i O’Connor, 2020.:11). Kulturni se sektor povezao još jače na globalnoj razini ${ }^{4}$, napravljen je niz ad hoc studija ${ }^{5}$, a istraživači i istraživačice u polju kulture također su pokušali odgovoriti na veliki broj upita o stanju u sektoru (Banks, 2020.; Banks i O’Connor, 2020.; Comunian i England, 2020.). Globalna kriza uzrokovana pandemijom koronavirusa uspjela je na vidjelo iznijeti svu ranjivost sektora kulture, neodrživost načina financiranja zasnovanog na tržišnim principima i projektnom tipu rada te nužnost drukčijeg gledanja na kulturu i na stvaranje održivijih modela razvoja tog sektora.

Potreba da se vidi kakva je točno situacija na terenu i kako je pandemija bolesti COVID-19 djelovala na kulturni sektor u jugoistočnoj Europi bila je glavna motivacija za istraživanje „Sada je samo vidljivije: život i rad kulturnih radnika i radnica u vremenu korona pandemije" 6 provedeno od Centra za empirijske studije kulture jugoistočne Europe (CESK). Osnovni ciljevi istraživanja bili su:

- dokumentirati uvjete života i rada umjetnika/ica i drugih kulturnih radnika i radnica u društvima jugoistočne Europe za vrijeme globalne pandemije izazvane novim koronavirusom u periodu dok se kriza odvija kako bi se dobili uvidi u efekte koje je ona imala na njihov život i rad

- $\quad$ utvrditi jesu li u tom periodu postojali mehanizmi pomoći umjetnicima i kulturnim radnicima i radnicama (kako na nacionalnoj tako i na lokalnoj razini ili od međunarodnih zaklada, umjetničkih udruženja, kolega/ica ili javnosti)

- da se pokušaju identificirati tendencije koje će, kao posljedica krize, vrlo vjerojatno promijeniti i život i stvaralaštvo kulturnih radnika i radnica u društvima jugoistočne Europe.

\footnotetext{
${ }^{4}$ Već na samom početku pandemije organiziran je niz online konferencija te diskusija od međunarodnih kulturnih mreža, a koje su uključivale i brojne europske i globalne donosioce odluka. Izdvojimo npr. International Virtual Conference COVID-19 crisis \& Emergency Funding Mechanisms, konferenciju organiziranu od Culture Funding Watch i Rambourg Foundation u ožujku 2020. godine; zatim A Cultural Deal for Europe u studenom 2020. godine, organiziranu od ključnih aktera na polju europskih kulturnih politika - mreže Culture Action Europe te zaklada European Cultural Foundation i Europa Nostra.

5 Npr. IETM izvještaj (Polivtseva, 2020.), OECD (2020.), UNESCO (2020.).

6 Engleska verzija naslova istraživanja Now it is Only More Visible: Life and Work of Cultural Workers in the Times of the Corona Pandemic. Voditelj je istraživanja prof. dr. sc. Predrag Cvetičanin, Centar za empirijske studije kulture jugoistočne Evrope (CESK) te Sveučilište u Nišu, Srbija. Detaljnije o samom istraživanju i korištenoj metodologiji te uzorku u sljedećem poglavlju.
} 
Slijedeći ciljeve istraživanja u ovom radu bit će pružen pregled ključnih rezultata vezanih uz prihode, poslove i mjere u kulturnom sektoru u istraživanim zemljama jugoistočne Europe. $\mathrm{Na}$ taj će se način dobiti komparativan uvid u učinke prvog vala globalne krize uzrokovane pandemijom bolesti COVID-19 na život i rad kulturnih radnika i umjetnica u jugoistočnoj Europi, čime će se stvoriti i temeljitija podloga za drukčije shvaćanje uloge kulturnog sektora te posljedično i mijenjanje instrumenata javnih politika u tom području.

\section{Metodologija i uzorak}

Rad se temelji na podacima međunarodnog istraživanja „Sada je samo vidljivije: život i rad kulturnih radnika i radnica u vremenu korona pandemije“, koje je u periodu od svibnja do srpnja 2020. godine proveo Centar za empirijske studije kulture jugoistočne Europe (CESK) u suradnji s partnerima iz jugoistočne Europe. ${ }^{7}$ Istraživanje je bilo eksplorativnog karaktera i koristilo je mješovite metode, gdje je osnova za istraživanje bio online anketni upitnik s 44 pitanja, od kojih su posljednja tri bila otvorenog tipa. Cilj otvorenih pitanja bio je dati glas ispitanicima i ispitanicama te dobiti bogatije uvide i kontekstualne podatke kvalitativnog tipa, za čiju je obradu korištena tematska analiza. Upitnik je distribuiran kroz kontakte partnerskih organizacija iz jugoistočne Europe elektroničkom poštom profesionalnih udruženja, mreža nevladinih organizacija, zaklada te kroz različite mailing liste i kanale društvenih mreža (Facebook, Instagram i sl.). ${ }^{8} \mathrm{U}$ istraživanju je korišten prigodni uzorak, a u konačnici je anketirano ukupno 576 ispitanika i ispitanica u odabranim zemljama jugoistočne Europe. ${ }^{9}$ Kako zbog nedovoljnog odaziva u Albaniji te na Kosovu nije bio prikupljen zadovoljavajući broj ispitanika, u analizi podataka istraživanja korišteni su rezultati za Bosnu i Her-

${ }^{7}$ Autorica članka jedna je od suradnica projekta iz Hrvatske, gdje je u provedbi upitnika pomoć došla i od Zaklade „Kultura nova“. Regionalni partneri u projektu uključivali su partnere iz organizacija Asociacija i Glej (SLO), Expeditio (CG), Lumbardhi Foundation (Kosovo), SCCA (MK) te FONDACIONI RRUGA ME PISHA (AL). Projekt je nastavak istraživačkih napora Centra za empirijske studije kulture jugoistočne Evrope u mapiranju situacije prvenstveno u sektoru nezavisne kulture u zemljama jugoistočne Europe, koji su rezultirali nizom istraživačkih projekata u posljednjih deset godina: NonInstitutional Partakers of Cultural Policy in Serbia, Montenegro and Macedonia (2009. - 2010.); Within or Without the System - Freelancers on their Work in Creative Industries (2014.); Out of the Margins - Research and Policy-Making on Independent Cultural Scenes in South-East European Societies (2015. - 2016.); The Socio-economic Status and the Lifestyle/Workstyle of the Employed/Engaged in the Civic Cultural Sector of South-East European Societies (2016. - 2017.). U sljedećoj fazi istraživanja planira se i provedba 30 - 40 dubinskih intervjua sa sudionicima istraživanja koji su u anketi dali privolu da ih se kontaktira u nastavku provođenja istraživanja.

8 Upitnik je u Albaniji i Kosovu distribuiran na albanskom jeziku, u Sjevernoj Makedoniji na makedonskom, u Hrvatskoj i Sloveniji na engleskom, dok je u ostalim zemljama distribuiran u BH-HR-CG-SR inačici.

9 I premda nije moguće direktno prenositi dobivene rezultate s uzorka na populaciju, on dovoljno jasno ukazuje na trendove o kojima govorimo u ovom tekstu. 
cegovinu, Crnu Goru, Hrvatsku, Sjevernu Makedoniju, Sloveniju i Srbiju. Dakle, konačni uzorak na kojem su provedene analize bio je 544 ispitanika i ispitanica iz navedenih šest zemalja. Upitnik je u Hrvatskoj ispunilo 110 ispitanika i ispitanica iz svih krajeva Hrvatske, od čega je bilo 76 ispitanika i ispitanica sa sjedištem u Zagrebu ${ }^{10}$, dok ih je 34 bilo iz drugih gradova Hrvatske. Sličan odnos glavni grad - ostali gradovi bio je i u drugim zemljama, osim Crne Gore, gdje je podjednak broj bio iz glavnog grada i ostalih gradova. Uz sociodemografske podatke u upitniku su prikupljeni i podaci o ekonomskim prilikama ispitanika i njihovih kućanstava (samoprocjenu prihoda ispitanika i njihovih kućanstava prije pandemije te u mjesecima ožujku i travnju 2020. godine, dodatni posao (ukoliko ga obavljaju), alternativni izvori prihoda, uvjeti stanovanja, štednja ili bankarski krediti prije pandemije, zdravstveno i mirovinsko osiguranje itd.). Upitnikom su prikupljeni i podaci o njihovom trenutačnom radnom statusu i području angažiranja, podaci o projektima u koje su uključeni i njihov status tijekom pandemije te podaci o mehanizmima sigurnosti i podrške koji su im pruženi tijekom pandemije (pomoći na nacionalnoj, lokalnoj razini, pomoći međunarodnih organizacija i zaklada te domaćih profesionalnih organizacija ili drugi tip pomoći iz sektora). Za zaposlene i angažirane u organizacijama civilnog društva dodatno su traženi podaci o procjeni pada prihoda i budžeta organizacije, statusima projekata u organizaciji te izvorima prihoda organizacije.

U prvom otvorenom pitanju u anketi ispitanici i ispitanice zamoljeni su da ukratko napišu kakav dodatan tip mjera smatraju da bi trebao biti uveden (i od kojih dionika) da bi se olakšao život i rad umjetnika/ica, kulturnih radnika/ica i organizacija. U drugom otvorenom pitanju ispitanici su zamoljeni da napišu koje je negativne utjecaje kriza uzrokovana pandemijom bolesti COVID-19 imala na njihov život i rad, a u trećem je pitanju traženo da opišu je li kriza prouzrokovala i neke pozitivne efekte u njihovom životu i radu. U navedenim otvorenim odgovorima u slučaju ispitanika i ispitanica iz Hrvatske mnogi su se dotaknuli i dodatne krize uzrokovane potresom u Zagrebu 22. ožujka 2020. godine, koji je također izraženo djelovao na zagrebačku kulturnu scenu, ali i hrvatsku kulturu općenito zbog važne uloge koju Zagreb kao glavni grad ima na cjelokupni kulturni sektor u Hrvatskoj. Ujedno valja uzeti u obzir $\mathrm{u}$ analizi i činjenicu da je u Hrvatskoj u trenutku provođenja ankete krenulo provođenje tek prvog vala mjera za kulturni sektor na nacionalnoj razini, dok je u trenutku pisanja ovog teksta odobren i treći val mjera za kulturni sektor.

Ovo je istraživanje za cilj imalo zahvatiti širi krug ispitanika iz cjelokupnog kulturnog sektora, počevši od onih zaposlenih u javnim kulturnim ustanovama, zatim zaposlenih u kulturnim industrijama, preko slobodnih umjetnika/ica i eksperata/ica pa

\section{0}

Dosadašnja istraživanja ukazuju na centralizaciju kulturne proizvodnje na grad Zagreb (Primorac, 2021.), tako da smo smatrali da je ovakav postotak odgovora iz Zagreba u odnosu na ostale gradove Hrvatske zadovoljavajući. 
sve do zaposlenih u organizacijama civilnog društva u području suvremene kulture i umjetnosti. Kako je prikazano u tablici 1, u ukupnom su uzorku najviše bili zastupljeni slobodni umjetnici/e i eksperti/ce (43,0\%), potom zaposleni u javnim kulturnim institucijama $(18,4 \%)$, zatim u gotovo podjednakom postotku zaposleni u privatnoj tvrtki i samozaposleni (16,5\%) i zaposleni ili angažirani u NVO-u (16,00\%) te ostali (6,1\%). Za Hrvatsku je taj omjer bio nešto drukčiji, ali su također u uzorku najviše bili zastupljeni slobodni umjetnici/e i eksperti/ce (42,7\%). Međutim, za razliku od ukupnog uzorka, za Hrvatsku su potom u uzorku bili zastupljeni zaposleni ili angažirani u NVO-u (26,4\%), zatim zaposleni u privatnoj tvrtki i samozaposleni $(17,3 \%)$ te naposljetku zaposleni u javnim kulturnim institucijama (12,7\%). Dakle, i u ukupnom uzorku i u uzorku za Hrvatsku najviše su zastupljeni slobodni umjetnici/e i eksperti/ ce, tj. oni koji nemaju stalne prihode, koji su zbog projektnog tipa rada u najranjivijoj poziciji u vremenima krize.

Tablica 1.

Uzorak prema zemlji i statusu zaposlenosti

\begin{tabular}{|c|c|c|c|c|c|c|c|}
\hline Država & & $\begin{array}{c}\text { Zaposleni } \\
\text { u javnoj } \\
\text { kulturnoj } \\
\text { instituciji }\end{array}$ & $\begin{array}{c}\text { Zaposleni } \\
\text { u privat- } \\
\text { noj tvrtki } \\
\text { i samoza- } \\
\text { posleni }\end{array}$ & $\begin{array}{c}\text { Zaposleni } \\
\text { ili } \\
\text { angažirani } \\
\text { u NVO }\end{array}$ & $\begin{array}{l}\text { Slobodni } \\
\text { umjetnici } \\
\text { i eksperti }\end{array}$ & Ostalo & Ukupno \\
\hline \multirow{3}{*}{ BA } & $N$ & 18 & 5 & 12 & 8 & 8 & 51 \\
\hline & $\%$ unutar zemlje & $35,30 \%$ & $9,80 \%$ & $23,50 \%$ & $15,70 \%$ & $15,70 \%$ & $100,00 \%$ \\
\hline & $\%$ unutar zaposlenosti & $18,00 \%$ & $5,60 \%$ & $13,80 \%$ & $3,40 \%$ & $24,20 \%$ & $9,40 \%$ \\
\hline \multirow{3}{*}{ HR } & $N$ & 14 & 19 & 29 & 47 & 1 & 110 \\
\hline & $\%$ unutar zemlje & $12,70 \%$ & $17,30 \%$ & $26,40 \%$ & $42,70 \%$ & $0,90 \%$ & $100,00 \%$ \\
\hline & $\%$ unutar zaposlenosti & $14,00 \%$ & $21,10 \%$ & $33,30 \%$ & $20,10 \%$ & $3,00 \%$ & $20,20 \%$ \\
\hline \multirow{3}{*}{ ME } & $N$ & 18 & 4 & 13 & 26 & 8 & 69 \\
\hline & $\%$ unutar zemlje & $26,10 \%$ & $5,80 \%$ & $18,80 \%$ & $37,70 \%$ & $11,60 \%$ & $100,00 \%$ \\
\hline & $\%$ unutar zaposlenosti & $18,00 \%$ & $4,40 \%$ & $14,90 \%$ & $11,10 \%$ & $24,20 \%$ & $12,70 \%$ \\
\hline \multirow{3}{*}{ MK } & $N$ & 13 & 9 & 11 & 16 & 6 & 55 \\
\hline & $\%$ unutar zemlje & $23,60 \%$ & $16,40 \%$ & $20,00 \%$ & $29,10 \%$ & $10,90 \%$ & $100,00 \%$ \\
\hline & $\%$ unutar zaposlenosti & $13,00 \%$ & $10,00 \%$ & $12,60 \%$ & $6,80 \%$ & $18,20 \%$ & $10,10 \%$ \\
\hline \multirow{3}{*}{ RS } & $N$ & 36 & 18 & 18 & 126 & 10 & 208 \\
\hline & $\%$ unutar zemlje & $17,30 \%$ & $8,70 \%$ & $8,70 \%$ & $60,60 \%$ & $4,80 \%$ & $100,00 \%$ \\
\hline & $\%$ unutar zaposlenosti & $36,00 \%$ & $20,00 \%$ & $20,70 \%$ & $53,80 \%$ & $30,30 \%$ & $38,20 \%$ \\
\hline \multirow{3}{*}{ SI } & $N$ & 1 & 35 & 4 & 11 & 0 & 51 \\
\hline & $\%$ unutar zemlje & $2,00 \%$ & $68,60 \%$ & $7,80 \%$ & $21,60 \%$ & $0,00 \%$ & $100,00 \%$ \\
\hline & $\%$ unutar zaposlenosti & $1,00 \%$ & $38,90 \%$ & $4,60 \%$ & $4,70 \%$ & $0,00 \%$ & $9,40 \%$ \\
\hline \multirow{3}{*}{ TOTAL } & $N$ & 100 & 90 & 87 & 234 & 33 & 544 \\
\hline & $\%$ unutar zemlje & $18,40 \%$ & $16,50 \%$ & $16,00 \%$ & $43,00 \%$ & $6,10 \%$ & $100,00 \%$ \\
\hline & $\%$ unutar uzorka & $100,00 \%$ & $100,00 \%$ & $100,00 \%$ & $100,00 \%$ & $100,00 \%$ & $100,00 \%$ \\
\hline
\end{tabular}


Unutar uzorka bila su zastupljena sva područja umjetničkog i kulturnog djelovanja, koja grupirana u četiri glavna područja (koja ćemo ovdje ugrubo kategorizirati) pokazuju da su u ukupnom uzorku najviše bile zastupljene vizualne umjetnosti (likovna umjetnost, fotografija, dizajn, digitalne umjetnosti i multimedija) - 33,1\%, zatim izvedbene umjetnosti (kazalište, ples, glazba) u iznosu od $31,3 \%$, potom ostale djelatnosti (kulturne baštine, književnosti, arhitekture i obrta) s 20,4\% te naposljetku audiovizualne djelatnosti (film, televizija i radio) s 15,30\%. Ukoliko pogledamo podatke za Hrvatsku, omjer u uzorku slijedi dijelom onaj ukupnog uzorka, gdje su također najviše bili zastupljeni ispitanici iz vizualnih umjetnosti $(27,30 \%)$, potom ostale djelatnosti $(27,30 \%)$, zatim izvedbene umjetnosti $(24,50 \%)$ te naposljetku audiovizualne djelatnosti (20,90\%). Gledajući pojedinačno područja umjetničkog i kulturnog djelovanja, za Hrvatsku je najviše ispitanika dolazilo iz područja filma (18,20\%), potom likovne umjetnosti $(12,70 \%)$, književnosti $(11,80 \%)$, plesa $(11,80 \%)$ te kazališta $(10,00 \%) .{ }^{11}$

\section{Zaustavljeni poslovi, prepolovljeni prihodi i (samo)eksploatacijske prakse}

Od samog početka krize kulturni sektor kako diljem Europe tako i na globalnoj razini ukazivao je na tešku situaciju u kojoj su se našli deseci tisuća umjetnika/ica i kulturnih radnika/ica diljem svijeta kroz niz apela i otvorenih pisama. Ministarstva kulture i različite kulturne i audiovizualne agencije diljem svijeta pokušale su pravovremeno i kroz različit tip mjera odgovoriti na zahtjeve sektora, koji su ukazivali na rapidan pad primanja u sektoru te na sve težu radnu i životnu situaciju zaposlenih. ${ }^{12} \mathrm{Na}$ samom početku pandemije, kao i u mjesecima kada su krenule mjere koje su uključivale različit tip karantene, podataka o stanju u kulturnom sektoru bilo je malo, poglavito u zemljama jugoistočne Europe. U određenim zemljama ministarstva kulture i medija te informiranja počela su s kreiranjem i odobravanjem mjera, dok su radnici i radnice iz sektora naglašavali teške uvjete $s$ kojima se susreću. ${ }^{13} \mathrm{U}$ hrvatskom slučaju krizna situacija uzrokovana pandemijom naknadno je bila naglašena posljedicama potresa u Zagrebu, koji je imao velik utjecaj na radne i životne uvjete kako umjetnika/ica tako i kulturnih radnika/ica. Upravo nas je taj nedostatak adekvatnih informacija o stanju u zemljama jugoistočne Europe inspirirao da pokrenemo ovo istraživanje, te smo se u prvom dijelu istraživanja fokusirali upravo na podatke o prihodima, procjeni gubitka prihoda, obavljanju dodatnih poslova i pridruženim aktivnostima, što karakterizira rad u ovom sektoru kako je navedeno u uvodnom dijelu. Valja napomenuti da je u periodu nakon što je proveden online upitnik u sklopu ovog istraživanja Zaklada

\footnotetext{
11 Dodatni podaci o uzorku po zemljama i dobi te obrazovanju ispitanika/ica dostupni su u Prilogu.

12 Navedeni rad vidljiv je i kroz rezoluciju o oporavku europskog kulturnog sektora Europskog parlamenta: European Parliament resolution on the cultural recovery of Europe (2020/2708(RSP)).

13 Npr. za sektor izvedbenih umjetnosti vidi Polivtseva (2020.) ili podatke GESAC-a (European Grouping of Societies of Authors and Composers): https://authorsocieties.eu/covid-19-recovery-whats-thedamage-and-how-can-we-move-forward-2l
} 
„Kultura nova“ provela svoje istraživanje o utjecaju pandemije bolesti COVID-19 te potresa u Zagrebu na organizacije civilnog društva u području suvremene kulture i umjetnosti, čiji je izvještaj objavljen u prosincu 2020. godine (Krolo i sur. 2020.).

Prema podacima dobivenima online anketom, u svim istraživanim zemljama u odnosu na mjesečne prihode iz 2019. godine u ožujku i travnju 2020. godine došlo je do pada mjesečnih prihoda prema procjenama naših ispitanika $\mathrm{i}$ ispitanica. Kako je razvidno iz slike 1, za sve zemlje (osim Crne Gore) mjesečni prihod umjetnika/ica i kulturnih radnika/ica u istraživanim zemljama jugoistočne Europe u mjesecu travnju 2020. bio je gotovo prepolovljen u odnosu na prosječni mjesečni prihod u 2019. godini. Treba, dakako, napomenuti da su na slici 1 prikazani iznosi na nivou čitavog uzorka, dok su neki od ispitanika i ispitanica već u prvim mjesecima krize ostali bez ikakvih prihoda ili na minimalnim mjesečnim prihodima. Npr. gledajući podatke za ožujak 2020. godine, podaci pokazuju da u tom periodu 15 umjetnika nije uspjelo ostvariti nikakve prihode, dok je njih $146(26,8 \%)$ imalo prihode manje od $100 €$. U travnju 2020. godine situacija se pogoršala, pa je 28 ispitanika potpuno ostalo bez mjesečnih prihoda, dok su prihodi njih čak $168(30,9 \%)$ bili ispod $100 €$, kako su istaknuli kolege u preliminarnom predstavljanju podataka istraživanja (Cvetičanin i Dinić, 2020::25).

Slika 1.

Samoprocjena prosječnih mjesečnih prihoda ispitanika po zemljama u 2019. godini, prosječnih mjesečnih prihoda ispitanika u ožujku i travnju 2020. godine te prosjek za sve zemlje (u €)

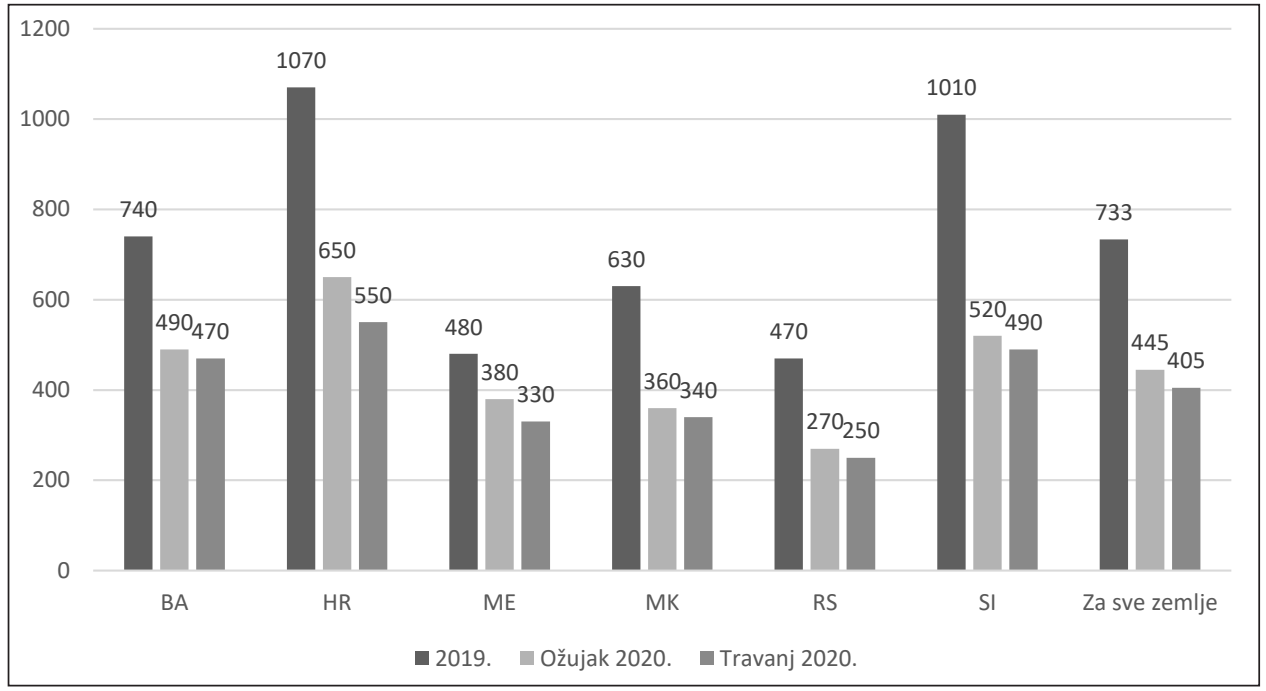

U Bosni i Hercegovini taj je procijenjeni gubitak prosječnog mjesečnog prihoda za travanj 2020. godine u odnosu na prosječni mjesečni prihod za 2019. godinu iznosio 270 EUR, za Crnu Goru 150 EUR, za Hrvatsku i Sloveniju po 520 EUR, Sjevernu Makedoniju 290 EUR te za Srbiju 220 EUR. Slijedom navedenog, također nas je zanimalo da ispitanici i ispitanice procijene koliki će biti gubitak njihovih ukupnih 
primanja u 2020. godini zbog odgoda i otkazivanja projekta te otkazivanja poziva na projekte. Tablica 2 donosi podatke za one ispitanike i ispitanice koji su mogli procijeniti gubitke primanja u 2020. godini $(\mathrm{N}=440)$. Kako je vidljivo iz tablice 2 , ispitanici $\mathrm{i}$ ispitanice $\mathrm{u}$ istraživanim zemljama očekivali su gubitke tijekom 2020. godine, gdje srednja vrijednost gubitaka za zemlje leži u rasponu između $3.000 €$ i $5.000 €$, dok je za Sloveniju procijenjeni gubitak primanja oko $8.000 €$. Navedeni su iznosi na razini otprilike polovine njihovih prihoda u 2019. godini kako pokazuju podaci ovog istraživanja. O razini ozbiljnosti situacije govori i podatak da većina ispitanika nije uspjela osigurati alternativni izvor prihoda u periodu ožujak - svibanj 2020. godine: radi se o $81,9 \%$ ispitanika i ispitanica u ukupnom uzorku koji nisu uspjeli osigurati alternativni izvor prihoda. Kada se gledaju podaci prema zemljama, situacija je povoljnija u Sloveniji i Hrvatskoj, gdje 68,5\% i 77,5\% ispitanika nije uspjelo osigurati alternativni izvor prihoda, u Bosni i Hercegovini 84,3\%, u Srbiji taj postotak iznosi 85,1\%, dok u Sjevernoj Makedoniji i Crnoj Gori čak 85,5\% nije uspjelo osigurati alternativni izvor prihoda u periodu ožujak - svibanj 2020. godine, upravo kada su doživjeli gore navedeni drastičan pad osnovnih prihoda. Pri tome valja istaknuti da je samo mali dio ispitanika i ispitanica u našem istraživanju imao određenu ušteđevinu na koju se mogao osloniti dolaskom globalne krize. Samo je četvrtina (24,8\%) ispitanika u uzorku imala ušteđevinu od $1.500 €$ i veću, ušteđevina još trećine bila je do $1.000 €$, dok više od trećine ispitanika (34,7\%) nije imalo nikakvu ušteđevinu (Cvetičanin i Dinić, 2020.: 25).

Tablica 2.

Procjena gubitka primanja u 2020. godini

\begin{tabular}{|c|c|c|c|c|c|c|c|c|c|c|}
\hline \multirow{2}{*}{$\begin{array}{l}\text { Država } \\
\text { prebivališta }\end{array}$} & & \multicolumn{8}{|c|}{$\begin{array}{l}\text { Prema Vašoj procjeni, koliki će biti gubitak Vaših primanja u 2020. godini } \\
\text { zbog odgoda i otkazivanja projekta te otkazivanja poziva na projekte? } \\
\text { (Iskazano u EUR) }\end{array}$} & \multirow[b]{2}{*}{ Ukupno } \\
\hline & & $\begin{array}{l}\text { Neće } \\
\text { biti } \\
\text { gubi- } \\
\text { taka }\end{array}$ & $\begin{array}{c}\text { Manje } \\
\text { od } \\
3.000 \\
\text { EUR }\end{array}$ & $\begin{array}{c}3.001 \\
- \\
5.000 \\
\text { EUR }\end{array}$ & $\begin{array}{c}5.001 \\
- \\
10.000 \\
\text { EUR }\end{array}$ & $\begin{array}{c}10.001 \\
- \\
15.000 \\
\text { EUR }\end{array}$ & $\begin{array}{c}15.001 \\
- \\
20.000 \\
\text { EUR }\end{array}$ & $\begin{array}{c}\text { Više od } \\
20.000 \\
\text { EUR }\end{array}$ & Ostalo & \\
\hline \multirow{2}{*}{ BA } & $\mathrm{N}$ & 7 & 11 & 5 & 3 & 3 & 1 & 4 & 2 & 36 \\
\hline & $\%$ & $19,4 \%$ & $30,6 \%$ & $13,9 \%$ & $8,3 \%$ & $8,3 \%$ & $2,8 \%$ & $11,1 \%$ & $5,6 \%$ & $100,00 \%$ \\
\hline \multirow{2}{*}{$H R$} & $\mathrm{~N}$ & 8 & 29 & 17 & 20 & 10 & 4 & 4 & 3 & 95 \\
\hline & $\%$ & $8,4 \%$ & $30,5 \%$ & $17,9 \%$ & $21,1 \%$ & $10,5 \%$ & $4,2 \%$ & $4,2 \%$ & $3,2 \%$ & $100,00 \%$ \\
\hline \multirow{2}{*}{ ME } & $\mathrm{N}$ & 11 & 12 & 14 & 5 & 2 & 0 & 2 & 3 & 49 \\
\hline & $\%$ & $22,4 \%$ & $24,5 \%$ & $28,6 \%$ & $10,2 \%$ & $4,1 \%$ & $0,0 \%$ & $4,1 \%$ & $6,1 \%$ & $100,00 \%$ \\
\hline \multirow{2}{*}{ MK } & $\mathrm{N}$ & 8 & 16 & 4 & 6 & 3 & 1 & 1 & 2 & 41 \\
\hline & $\%$ & $19,5 \%$ & $39,0 \%$ & $9,8 \%$ & $14,6 \%$ & $7,3 \%$ & $2,4 \%$ & $2,4 \%$ & $4,9 \%$ & $100,00 \%$ \\
\hline \multirow{2}{*}{ RS } & $\mathrm{N}$ & 16 & 58 & 41 & 20 & 9 & 1 & 11 & 11 & 167 \\
\hline & $\%$ & $9,6 \%$ & $34,7 \%$ & $24,6 \%$ & $12,0 \%$ & $5,4 \%$ & $0,6 \%$ & $6,6 \%$ & $6,6 \%$ & $100,00 \%$ \\
\hline \multirow{2}{*}{ SI } & $\mathrm{N}$ & 3 & 8 & 11 & 15 & 4 & 5 & 4 & 2 & 52 \\
\hline & $\%$ & $5,8 \%$ & $15,4 \%$ & $21,2 \%$ & $28,8 \%$ & $7,7 \%$ & $9,6 \%$ & $7,7 \%$ & $3,8 \%$ & $100,00 \%$ \\
\hline \multirow{2}{*}{ TOTAL } & $\mathrm{N}$ & 53 & 134 & 92 & 69 & 31 & 12 & 26 & 23 & 440 \\
\hline & $\%$ & $12,05 \%$ & $30,45 \%$ & $20,90 \%$ & $15,68 \%$ & $7,05 \%$ & $2,73 \%$ & $5,91 \%$ & $5,23 \%$ & $100,00 \%$ \\
\hline
\end{tabular}


Ovdje bi također valjalo napomenuti da su razine prihoda kulturnih radnika i radnica i u okolnostima izvan krize kakvu je donijela globalna pandemija u većini istraživanih zemalja niske. To se posebice odnosi na one zaposlene u organizacijama civilnog društva ili u statusu slobodnih umjetnika, kako su pokazala prethodna istraživanja na razini regije (Cvetičanin i sur., 2017.). Projektna orijentiranost te okolnosti nesigurnih i niskih primanja kulturne radnike i radnice često također dovodi i do paralelnog obavljanja poslova ili rada na dodatnim kako bi podmirili sve životne troškove (Primorac, 2010.). Pri tome su kod prvog radnici/e dovedeni u tu situaciju uslijed nemogućnosti odbijanja radnih zadataka, dok se u drugom slučaju radi o radu na poslovima koji nisu vezani uz kreativan rad, ali su neophodni kako bi se pokrila razdoblja bez rada na kulturnim i kreativnim projektima. Slijedom toga u našoj smo anketi ispitanike i ispitanice zamolili da navedu imaju li uz svoj umjetnički ili posao u kulturi i dodatni posao. Najviše pozitivnih odgovora bilo je u Crnoj Gori (56,5\%), zatim u Bosni i Hercegovini, gdje je 46\% ispitanika odgovorilo da je moralo imati dodatni poslovni angažman, u Srbiji je pozitivno na navedeno pitanje odgovorilo 34,3\% ispitanika, dok je u Sjevernoj Makedoniji taj postotak iznosio 25,5\%. Najmanji broj ispitanika koji je morao imati dodatni poslovni angažman je u Hrvatskoj (22,9\% te u Sloveniji $17,6 \%)$. Važno je za istaknuti da za skoro dvije trećine njih $(65,9 \%)$ taj dodatni posao donosi više od polovine ukupnih osobnih prihoda.

Djelomični podaci kako o radu u kreativnim industrijama u Hrvatskoj i jugoistočnoj Europi (Barada i Primorac, 2018.) tako i o uvjetima rada u organizacijama civilnog društva na području suvremene umjetnosti i kulture pokazuju gubljenje granica između poslovnog i privatnog vremena te stalnu uključenost u radni proces (Barada i sur., 2016.). Pri tome se mora naglasiti da je strukturna pozicija potfinancirane nezavisne kulturne scene puno ranjivija te upravo radnike i radnice iz tog podsektora stavlja u prekarniji položaj. Ujedno, istraživanja pokazuju da kulturni radnici i radnice (poglavito u nezavisnom kulturnom sektoru kao i u sektoru kulturnih industrija) kako zbog strukturnih nedostataka tako i zbog visoke identifikacije s radom u sektoru upražnjuju (neplaćeni) prekovremeni rad te samoeksploatirajuće prakse (Barada i sur., 2016.; Barada i Primorac, 2018.; Primorac, 2010.). Podaci istraživanja za jugoistočnu Europu također pokazuju kako je preko polovine anketiranih često ili uvijek radilo više od osam sati dnevno i preko 30\% često ili uvijek više od 40 radnih sati tjedno. Pored toga, između 30\% i 50\% često je ili uvijek radilo i noću, između 50\% i 60\% radi i vikendom, od $40 \%$ do $50 \%$ za vrijeme godišnjih odmora, a između $40 \%$ i čak $70 \%$ (u Bosni i Sloveniji) za taj prekovremeni rad nije bilo plaćeno, kako se navodi u preliminarnom prikazu našeg istraživanja (Cvetičanin i Dinić, 2020.:24). Kada govorimo o neplaćenom radu, upravo je u kulturnom sektoru važan doprinos i volonterskog rada. Nažalost, u Hrvatskoj kao ni u široj regiji nemamo podataka o udjelu volonterskog rada u kulturi općenito, premda bi nam takvi podaci bili dragocjeni za bolje procjenjivanje ukupne dinamike tržišta rada u kulturi. Štoviše, procjena podataka o volonterskom te ostalim vidovima neplaćenog rada u cjelini uvelike bi nam pomogla da se 
pokaže u kolikoj je mjeri rad u kulturi potplaćen te kako je cijena kulture i umjetnosti zapravo znatno veća. To je također bitno i u kontekstu procjena gubitaka u sektoru uslijed pandemije bolesti COVID-19, gdje je navedena dimenzija rada u kulturi bila zanemarena.

\section{Fragmentarna nacionalna $\mathbf{i}$ međunarodna podrška, sektorska solidarnost $\mathbf{i}$ mûk lokalnih policy makera}

Kako bi se u nekoj mjeri smanjile negativne posljedice utjecaja krize uzrokovane pandemijom bolesti COVID-19 na kulturni i medijski sektor, državna uprava te lokalne i regionalne uprave i samouprave diljem svijeta (u većoj ili manjoj mjeri) krenule su $s$ izradom mjera za podršku sektoru. ${ }^{14}$ Brzina donošenja mjera i red veličine kojom su neke vlade poput njemačke reagirale na negativne posljedice krize na kulturni sektor (otvarajući fondove u ukupnom iznosu od 30 milijardi eura) postavile su visoku ljestvicu očekivanja za kulturne radnike i umjetnike i u ostalim zemljama. Međutim, i brzina donošenja mjera te njihov opseg i brojnost vrlo je varirao od zemlje do zemlje, kako globalno tako i unutar Europske unije te u susjednim europskim zemljama. Upravo su u vrijeme provođenja online ankete (od svibnja do srpnja 2020. godine) za ovo istraživanje mnogi donositelji/ce odluka kako na nacionalnoj tako i na lokalnoj razini upravljanja u istraživanim zemljama tek krenuli (ukoliko su krenuli) s uvođenjem mjera, kako za sve sektore pa tako i za područje kulture. ${ }^{15}$ Podaci pokazuju da je, što se tiče nacionalne razine, većina vlada $\mathrm{u}$ istraživanim zemljama regije u navedenom periodu donijela barem neke mjere za ublažavanje posljedica krize. Kako je vidljivo iz tablice 3, najčešće se radilo o jednokratnoj višemjesečnoj pomoći za umjetnike/ice i kulturne radnike/ice, i to u visini minimalne zarade. U našem je uzorku u Hrvatskoj $(84,55 \%)$ i u Sloveniji $(78,43 \%)$ većina kulturnih radnika/ica dobila jednokratnu financijsku pomoć od države, što je u kontrastu s npr. Bosnom i Hercegovinom, gdje je tu pomoć dobilo manje od 9,8\% ispitanika. U Sjevernoj Makedoniji takav tip pomoći primilo je 50,91\% ispitanika, u Srbiji 49,04\% ispitanika/ica te u Crnoj Gori 33,33\% ispitanika/ica. U određenom broju istraživanih zemalja na nacionalnoj su razini bile dostupne i druge vrste mjera, koje su ispitanici i iskoristili. Tako npr. u Hrvatskoj je većina ispitanika iskoristila mogućnost produženja rokova za realizaciju projekata koji su bili prekinuti zbog izbijanja pandemije. U Hrvatskoj i Sjevernoj Makedoniji većem broju ispitanika/ica su isplaćena sredstava za odobrene projekte, uz dozvolu da ih se realizira kada to bude bilo moguće.

\footnotetext{
${ }^{14}$ Vidjeti npr. popise mjera prikupljenih od europskog projekta Compendium https://www.culturalpolicies.net/covid-19/ ili kreirane kroz priručnik UNESCO-a (UNESCO, 2020.).

${ }^{15}$ Valja napomenuti da smo morali biti fleksibilni u kreiranju popisa mjera za upitnik kako bismo pokušali zahvatiti različite društveno-političke kontekste istraživanih zemalja.
} 
Tablica 3.

Podrška na nacionalnoj razini, prema zemljama

\begin{tabular}{|c|c|c|c|c|c|c|c|c|}
\hline Vrsta podrške & & $\mathrm{BA}$ & $\mathrm{HR}$ & ME & MK & RS & SI & Total \\
\hline \multirow{3}{*}{$\begin{array}{l}\text { Jednokratna financijska } \\
\text { podrška za umjetnike i } \\
\text { kulturne radnike }\end{array}$} & $\mathrm{N}$ & 5 & 93 & 23 & 28 & 102 & 40 & 291 \\
\hline & \% podrška & $1,70 \%$ & $32,00 \%$ & $7,90 \%$ & $9,60 \%$ & $35,10 \%$ & $13,70 \%$ & $100,00 \%$ \\
\hline & $\%$ zemlja* & $9,80 \%$ & $84,55 \%$ & $33,33 \%$ & $50,91 \%$ & $49,04 \%$ & $78,43 \%$ & \\
\hline \multirow{3}{*}{$\begin{array}{l}\text { Isplata sredstava za sve } \\
\text { odobrene projekte, uz } \\
\text { dozvolu da se realiziraju } \\
\text { kada to bude moguće }\end{array}$} & $\mathrm{N}$ & 1 & 34 & 4 & 18 & 5 & 5 & 67 \\
\hline & \% podrška & $1,50 \%$ & $50,60 \%$ & $6,00 \%$ & $26,90 \%$ & $7,50 \%$ & $7,50 \%$ & $100,00 \%$ \\
\hline & $\%$ zemlja & $1,96 \%$ & $30,91 \%$ & $5,80 \%$ & $32,72 \%$ & $2,40 \%$ & $9,80 \%$ & \\
\hline \multirow{3}{*}{$\begin{array}{l}\text { Produženje rokova za } \\
\text { realizaciju odobrenih } \\
\text { projekata }\end{array}$} & $\mathrm{N}$ & 3 & 64 & 12 & 9 & 20 & 12 & 120 \\
\hline & \% podrška & $2,50 \%$ & $53,30 \%$ & $10,00 \%$ & $7,50 \%$ & $16,70 \%$ & $10,00 \%$ & $100,00 \%$ \\
\hline & $\%$ zemlja & $5,88 \%$ & $58,18 \%$ & $17,39 \%$ & $16,36 \%$ & $9,62 \%$ & $23,53 \%$ & \\
\hline \multirow{3}{*}{$\begin{array}{l}\text { Raspisivanje novih poziva } \\
\text { za projekte koji će biti } \\
\text { realizirani kada pandemija } \\
\text { prođe }\end{array}$} & $\mathrm{N}$ & 3 & 9 & 12 & 1 & 7 & 2 & 34 \\
\hline & \% podrška & $8,80 \%$ & $26,50 \%$ & $35,30 \%$ & $2,90 \%$ & $20,60 \%$ & $5,90 \%$ & $100,00 \%$ \\
\hline & $\%$ zemlja & $5,88 \%$ & $8,18 \%$ & $17,39 \%$ & $1,96 \%$ & $3,37 \%$ & $3,92 \%$ & \\
\hline \multirow{3}{*}{$\begin{array}{l}\text { Raspisivanje novih poziva } \\
\text { za projekte koji će biti } \\
\text { realizirani online }\end{array}$} & $\mathrm{N}$ & 2 & 34 & 22 & 5 & 4 & 2 & 69 \\
\hline & \% podrška & $2,90 \%$ & $49,30 \%$ & $31,90 \%$ & $7,20 \%$ & $5,80 \%$ & $2,90 \%$ & $100,00 \%$ \\
\hline & $\%$ zemlja & $3,92 \%$ & $30,91 \%$ & $31,88 \%$ & $9,80 \%$ & $1,92 \%$ & $3,92 \%$ & \\
\hline \multirow{3}{*}{\begin{tabular}{|} 
Pravo na socijalnu pomoć i \\
naknadu za nezaposlene dok \\
traje pandemija izazvana \\
novim koronavirusom
\end{tabular}} & $\mathrm{N}$ & 3 & 20 & 8 & 10 & 7 & 19 & 67 \\
\hline & \% podrška & $4,50 \%$ & $29,90 \%$ & $11,90 \%$ & $14,90 \%$ & $10,40 \%$ & $28,40 \%$ & $100,00 \%$ \\
\hline & \% zemlja & $5,88 \%$ & $18,18 \%$ & $11,59 \%$ & $18,18 \%$ & $3,37 \%$ & $37,25 \%$ & \\
\hline \multirow{3}{*}{$\begin{array}{l}\text { Moratorij na isplatu } \\
\text { rata kredita dok traje } \\
\text { pandemija izazvana novim } \\
\text { koronavirusom }\end{array}$} & $\mathrm{N}$ & 6 & 38 & 25 & 15 & 41 & 11 & 136 \\
\hline & \% podrška & $4,40 \%$ & $27,90 \%$ & $18,40 \%$ & $11,00 \%$ & $30,10 \%$ & $8,20 \%$ & $100,00 \%$ \\
\hline & $\%$ zemlja & $11,76 \%$ & $34,55 \%$ & $36,23 \%$ & $27,27 \%$ & $19,71 \%$ & $21,57 \%$ & \\
\hline \multirow{3}{*}{$\begin{array}{l}\text { Oslobađanje od plaćanja } \\
\text { poreza i taksi dok traje } \\
\text { pandemija izazvana novim } \\
\text { koronavirusom }\end{array}$} & $\mathrm{N}$ & 1 & 9 & 3 & 4 & 11 & 16 & 44 \\
\hline & \% podrška & $2,30 \%$ & $20,40 \%$ & $6,80 \%$ & $9,10 \%$ & $25,00 \%$ & $36,40 \%$ & $100,00 \%$ \\
\hline & \% zemlja & $1,96 \%$ & $8,18 \%$ & $4,35 \%$ & $7,27 \%$ & $5,29 \%$ & $31,37 \%$ & \\
\hline \multirow{3}{*}{$\begin{array}{l}\text { Odlaganja plaćanja } \\
\text { poreza i taksi dok traje } \\
\text { pandemija izazvana novim } \\
\text { koronavirusom }\end{array}$} & $\mathrm{N}$ & 1 & 19 & 2 & 6 & 28 & 28 & 84 \\
\hline & \% podrška & $1,30 \%$ & $22,60 \%$ & $2,40 \%$ & $7,10 \%$ & $33,30 \%$ & $33,30 \%$ & $100,00 \%$ \\
\hline & \% zemlja & $1,96 \%$ & $17,27 \%$ & $2,90 \%$ & $10,91 \%$ & $13,46 \%$ & $54,90 \%$ & \\
\hline \multirow{3}{*}{$\begin{array}{l}\text { Smanjivanje iznosa zakupa } \\
\text { prostora za rad dok traje } \\
\text { pandemija }\end{array}$} & $\mathrm{N}$ & 3 & 13 & 3 & 3 & 1 & 3 & 26 \\
\hline & \% podrška & $11,54 \%$ & $50,00 \%$ & $11,54 \%$ & $11,54 \%$ & $3,84 \%$ & $11,54 \%$ & $100,00 \%$ \\
\hline & \% zemlja & $5,88 \%$ & $11,82 \%$ & $4,35 \%$ & $5,45 \%$ & $0,48 \%$ & $5,88 \%$ & \\
\hline
\end{tabular}

*Odnosi se na postotak ispitanika koji su izjavili da su dobili navedenu pomoć u zemlji. 
U Crnoj Gori je pak nešto veći broj ispitanika/ica ukazao na raspisivanje novih poziva za projekte koji će biti realizirani kada pandemija prođe, pri čemu je u Crnoj Gori i u Hrvatskoj bio nešto veći postotak onih koji su javili na nove pozive za projekte koji mogu biti realizirani online. Ujedno valja istaknuti i kreiranje i korištenje niza mjera koje nisu isključivo financijske, a koje mogu dugoročno doprinijeti pozitivnim pomacima u sektoru istraživanih zemalja, pri čemu se misli na mjere poput oslobađanja od ili odlaganja plaćanja poreza i taksi dok traje pandemija, moratorija na otplatu kredita i slično. Kako je vidljivo u tablici 3, u Crnoj Gori i Hrvatskoj nešto je veći broj ispitanika/ica izjavilo da koristi mogućnost moratorija na otplatu kredita, dok u Sloveniji imamo najveći postotak onih koji koriste priliku za oslobađanje od ili odlaganje plaćanja poreza i taksi dok traje pandemija.

U velikoj je većini europskih zemalja, pa tako i u našim istraživanim zemljama, od ukupnog javnog financiranja za kulturni sektor financiranje na nacionalnoj razini vrlo je važno, dok značajnost lokalne i regionalne razine javnog financiranja varira od zemlje do zemlje. ${ }^{16} \mathrm{U}$ slučaju Hrvatske odnos udjela javnog financiranja kulture na različitim razinama prilično je konstantan u zadnjih dvadesetak godina (Primorac i Obuljen Koržinek, 2017.). U razdoblju 1999. - 2010. udio Ministarstva kulture u ukupnom javnom financiranju povećao se s $38 \%$ na 43\%, ali je od 2011. godine doživio pad s $41 \%$ u 2011 . na $35 \%$ u 2014., da bi u sljedećem razdoblju ponovno porastao na $42 \%$ u 2019. godini ${ }^{17}$. Posljedično, podaci pokazuju kako je javno financiranje na lokalnom i regionalnom nivou u Hrvatskoj raslo u periodu 2011. - 2014. godine, kada je i alokacija Grada Zagreba stagnirala. Dakle, u Hrvatskoj je javno lokalno financiranje kulture važno - prema podacima za 2019. godinu županije izdvajaju 4\% ukupnog javnog financiranja, općine 6\%, gradovi 33\%, dok samo na Grad Zagreb odlazi 15\% ukupnog javnog financiranja kulture u Hrvatskoj (Primorac, 2021.). Upravo je zato zabrinjavajuće što podaci našeg istraživanja pokazuju da je u Hrvatskoj kao i u svim ostalim zemljama jugoistočne Europe podrška kroz mjere pomoći kulturnom sektoru na lokalnoj razini uglavnom izostala. Prema podacima našeg istraživanja, samo su u malom broju slučajeva (manje od $5 \%$ ispitanika/ica u svim zemljama) umjetnici/e i kulturni radnici dobili financijsku pomoć na lokalnoj razini. U slučaju Hrvatske upravo su i neke od mjera koje su donesene na lokalnoj razini na njoj pokušale biti osporavane, kao na primjeru Grada Zagreba ${ }^{18}$, dok su rijetki slučajevi gradova i županija koji su u pandemijskoj situaciji odlučili podržati kulturni sektor.

\footnotetext{
16 Npr. u zemljama poput Njemačke te Španjolske zbog unutarnjeg ustroja regionalna je razina financiranja vrlo važna.

17 Pri čemu treba uzeti u obzir da je nivo državnog financiranja u 2018. godini umanjen za iznos koji sada Grad Zagreb izdvaja za HNK Zagreb.

18

Uzmimo za primjer Grad Zagreb kao gorespomenutog velikog financijera kulturnog sektora, gdje je nedostatak dosljednosti u provođenju mjera doveo do apsurdnog „ZAKLJUČKA o stavljanju izvan snage Zaključka o stavljanju izvan snage Zaključka o hitnoj isplati sredstava za javne potrebe u kulturi i pokrivanju troškova najma i materijalnih troškova prostora za rad“ donesenog od Gradske skupštine Grada Zagreba 25. lipnja 2020. godine.
} 
U sklopu svojeg istraživanja željeli smo također istražiti i u kojoj su mjeri različite međunarodne zaklade i mreže $s$ jedne strane te profesionalne asocijacije i različiti načini udruživanja s druge strane bili otvoreni za pomoć kulturnom sektoru u zemljama jugoistočne Europe. Broj identificiranih mjera diljem regije nije bio velik u obama slučajevima, a najviše je zastupljenih mjera od zaklada, odnosno drugih donatorskih organizacija prepoznato u Hrvatskoj (22,7\%) i Sloveniji (27,5\%). Najviše je bilo razumijevanja kroz produženje rokova za realizaciju odobrenih projekata te odobrenja jednokratne novčane pomoći od zaklada. Pomoć od asocijacija, mreža i drugih vidova organiziranja podrške poput crowdfundinga bila je prisutna najviše u Srbiji (49\%), zatim u Sloveniji $(45,1 \%)$ i u Hrvatskoj $(36,4 \%)$, gdje su ispitanici bili potpomognuti od svojih strukovnih udruženja ili od mreža uspostavljenih na nacionalnom nivou. Uglavnom se tu radilo o različitim vidovima jednokratne novčane pomoći te organiziranju online programa uz mogućnost donacija. Ovdje je važno istaknuti upravo taj element solidarnosti unutar sektora koji se pojavio u više zemalja u regiji, gdje su (u nekim slučajevima po prvi put) surađivala različita profesionalna udruženja, kulturne udruge i nezavisni profesionalci, koji su, uz kreiranje apela i lobiranje za pomoć sektoru naglašavanjem važnosti različitih tipova mjera, i sami organizirali skupljanje sredstava i njihovu distribuciju umjetnicima i kulturnim radnicima. ${ }^{19}$

\section{Zaključak}

Prethodna istraživanja rada u kulturnom i kreativnom sektoru ukazivala su na mnoge elemente ranjivosti sektora, koji su prvenstveno vezani uz prekarne oblike rada, nesigurno i nestabilno financiranje sektora, ali i na otpornost samog sektora u vremenima krize koja se najčešće pripisivala „fleksibilnosti“ i „kreativnosti“ upravo njegovih zaposlenika/ica. Negativne strane nesigurnog projektnog rada, nestalnih primanja, nužnosti rada na dodatnim poslovima te različitim oblicima samoeksploatacije bile su zamagljivane kako bi se naglasila važnost fleksibilnosti i kreativnosti kao ključnih karakteristika (kulturnog) radnika s portfeljem. Upravo takav tip radnika/radnice, koji se uzima i kao simbol tržišnog uspjeha, navodi se da doprinosi otpornosti organizacije

19 Npr. organizacija Fonda solidarnosti kulturnih radnika i radnica Srbije, koji je nastao na inicijativu Nezavisne kulturne scene Srbije (NKSS), a u suradnji s Udruženjem likovnih umetnika Srbije, Savezom udruženja likovnih umetnika Vojvodine, Servisa za savremeni ples Stanica, organizacije BAZAART i srpske sekcije Međunarodnog udruženja likovnih kritičara - AICA. Primjeri iz Slovenije uključuju kampanje „Solidarnost s kulturom“, koju je pokrenula Zaklada Igor Zabel zajedno s Crvenim križem sredinom ožujka 2020. godine, pri čemu su se skupljale donacije za kulturne radnike čija je egzistencija ugrožena, te javne akcije Društva Asociacija koje okuplja udruge u kulturi te samostalne kulturne radnike. Na Kosovu je upravo kroz samoorganizaciju i zagovor kulturnih radnika u finalnu verziju vladinog paketa pomoći uključen i zaseban fond Umjetnost solidarnosti. U Hrvatskoj je pak otvoreno pismo predsjedniku Vlade, potpredsjedniku Vlade i ministrici kulture u prosincu 2020. godine potpisalo 165 umjetnika/ica, dok su se po prvi put za radna prava radnika/ica u kulturi i umjetnosti zauzela udruženja koja o toj temi dotad nisu značajnije lobirala, kao npr. Udruga koncertnih promotora, HGU i sl. 
u kojoj djeluje te može biti „za primjer“ i radnicima u drugim sektorima. Međutim, globalna pandemija uzrokovana virusom SARS-CoV-2 ogolila je ono na što su istraživači i istraživačice već godinama ukazivali, a to je ranjivost i nesigurnost kako kulturnog rada tako i samog kulturnog sektora i neodrživost dosadašnjeg modela financiranja kulture koji u fokus stavlja projekt i tržišni pristup. Podaci su na globalnoj razini ukazivali na kritičnu situaciju u sektoru, na izostanak poslova, drastičan pad primanja kulturnog radništva te potrebu za žurnim djelovanjem u sektoru. Premda su podaci ovog istraživanja dobiveni prigodnim uzorkom, oni ipak pokazuju kako je u periodu prvog vala pandemije situacija u zemljama jugoistočne Europe slijedila navedene globalne trendove drastičnog pada prihoda, projekciju daljnjeg gubitka primanja tijekom nastavka krize, pri čemu su i dalje prisutne (samo)eksploatacijske prakse zaposlenika i zaposlenica u sektoru. U hrvatskom slučaju cijela je ta situacija dodatno pogoršana potresom u Zagrebu u periodu istraživanja, a poslije i potresom u Sisačko-moslavačkoj županiji, koji su imali utjecaj na ukupnu kulturnu infrastrukturu. Podaci objavljeni u pilot istraživanju Zaklade „Kultura nova“ također potkrepljuju navedene podatke i produbljuju podatke za organizacije civilnog društva u kulturi (Krolo i sur., 2020.).

Međutim, rane mjere koje su donošene tijekom prvog vala pandemije koronavirusa u istraživanim zemljama ukazuju kako na sličnosti tako i na razlike u policy pristupima. Kada govorimo o sličnostima, one se prvenstveno očituju u dimenziji nedonošenja lokalnih kulturnopolitičkih mjera u svim zemljama, što je u zemljama poput Hrvatske, gdje su lokalna izdvajanja za kulturu važna, vrlo problematična činjenica. Kada govorimo pak o razlikama, one se očituju u vidu mjera na nacionalnoj razini između država, gdje je za Hrvatsku, Sloveniju te donekle i Srbiju raznolikost i brojnost mjera prisutna, dok u ostalim zemljama one uvelike izostaju. Nedostatak navedenih mjera može se pripisati i kontinuiranoj marginalizaciji kulture općenito, marginalizaciji rada u kulturi specifično te jačanju tržišnog diskursa za kulturu u istraživanim zemljama. U hrvatskom slučaju to je vidljivo kroz niski status kulturne politike kao javne politike te kroz nisku razinu financiranja kulture, gdje budžet za kulturu već godinama ne prelazi 1\% (Primorac, 2021.). U takvom kontekstu mogli bismo se složiti s rezultatima koje nam donose Betzler i sur. (2020.) u svojoj analizi ranih mjera za kulturni sektor u Češkoj, Nizozemskoj, Portugalu, Sloveniji i Švicarskoj, gdje ističu kako se u njima vidi da su one razvijene u kontekstu složene interakcije prioriteta javne politike tijekom posljednjih godina. U tim su prioritetima intenzitet državnog sudjelovanja, ekonomska situacija prije pandemije i sklonost samozapošljavanju u društvu ključni za razumijevanje usvajanja specifičnih mjera politike u svim zemljama. Mogli bismo nadodati da se u odabranim zemljama jugoistočne Europe može zapravo govoriti i o nedostacima prioriteta javne politike i održavanju određenog statusa quo (Stubbs, 2019.). Dakle, problemi koje je prvi val pandemije otvorio samo se naslanjaju na (i negdje produbljuju) već započete procese, dok razvoj mjera reflektira već postojeću konjunkturu u odabranim zemljama. Bit će potrebno istražiti je li taj trend nastavljen i u drugom (te sada već i trećem) valu pandemije te jesu li vidljive nove promjene u pristupu mjerama. 
Naposljetku valja naglasiti da podaci istraživanja ukazuju na važne elemente solidarnosti unutar sektora, koji su vidljivi kroz umrežavanja profesionalnih udruženja koja dosad nisu surađivala, kroz akcije lobiranja i pisanja apela kako državnoj upravi tako i lokalnoj upravi i samoupravi kako bi se potaknula transparentnost donošenja mjera ili uopće njihovog provođenja. U većini zemalja u regiji pokrenute su i crowdfunding kampanje za kolegice i kolege u sektoru koji su ostali bez primanja te su stvorene i pojačane poveznice između kulturnih radnika/ica kako regionalno tako i međunarodno. Upravo ti elementi solidarnosti, međusobnog podupiranja, stvaranja novih kreativnih rješenja unutar i među organizacijama često se naglašavaju i kao ključni elementi otpornosti sektora (Krolo i sur., 2020.). Navedena otpornost počiva u visokoobrazovanoj, vrlo angažiranoj i predanoj radnoj snazi, koja se identificira s radom u sektoru i subjektivno je vrlo involvirana u sam proces rada i u njegov krajnji rezultat, gdje se granice između privatnog i poslovnog života gube. Međutim, upravo ta kontinuirana uključenost u proces, uz potfinanciranost sektora koji ujedno ne može zaposliti dovoljan broj radnika/ica, stvara i prepreke koje se očituju u samoeksploatacijskim praksama, a koje često rezultiraju pregorenošću i posljedično željom za napuštanjem rada u sektoru (Barada i sur. 2016.; Cvetičanin i Dinić, 2020.). Na takvoj „otpornosti“ ne može ležati daljnja budućnost kulturnog sektora, već se upravo ova situacija mora iskoristiti kako bi se propitao dosadašnji pristup kulturi, njenoj ulozi u društvu te posljedično kreiranju održivijih modela za razvoj sektora.

\section{Literatura}

1. Banks M. (2020). The work of culture and C-19. European Journal of Cultural Studies. 23 (4): 648-654. doi:10.1177/1367549420924687

2. Banks, M. and O'Connor, J. (2020). “A plague upon your howling”: artand culture in the viral emergency. Cultural Trends. DOI: 10.1080/09548963.2020.1827931

3. Barada, V. (2012). Žensko iskustvo rada u kreativnim industrijama - primjer dizajnerica vizualnih komunikacija u Hrvatskoj. Doktorska disertacija. Zagreb: Filozofski fakultet Sveučilišta u Zagrebu.

4. Barada, V.; Primorac, J. i Buršić, E. (2016). Osvajanje prostora rada. Uvjeti rada organizacija civilnog društva na području suvremene kulture i umjetnosti. Zagreb: Zaklada "Kultura nova".

5. Barada, V. and Primorac, J. (2018). In the Golden Cage of Creative Industries: Public-Private Valuing of Female Creative Labour, i: Bilić, P.; Primorac, J. and Valtysson, B. (Eds.). Technologies of Labour and the Politics of Contradiction. Palgrave Macmillan, 121-139.

6. Betzler, D.; Loots, E.; Prokůpek, M.; Marques, L.; Grafenauer, P. (2020). COVID-19 and the arts and cultural sectors: investigating countries' contextual factors and early policy measures. International Journal of Cultural Policy, DOI: $10.1080 / 10286632.2020 .1842383$ 
7. Comunian, R. and England, L. (2020). Creative and cultural work without filters: COVID-19 and exposed precarity in the creative economy. Cultural Trends, 29:2: 112-128. DOI: 10.1080/09548963.2020.1770577

8. Cvetičanin, P. i Dinić, J. (2020). Sada je samo vidljivije (ako ima ko da vidi). MANEK Magazin nezavisne kulture, 9: 22-33.

9. Cvetičanin, P. i sur. (2017). 'The Socio-economic Status and the Lifestyle/ Workstyle of the Employed/Engaged in the Civic Cultural Sector of South-East European Societies'. (Ljubaznošću autora, više na poveznici: https://tinyurl. com/u3kzmb3p).

10. Department for Culture, Media and Sport - DCMS (2003). „Creative industries fact file“. DCMS, Creative Industries Division. http://www.culture.gov. uk/PDF/ci fact file.pdf. (Pristupljeno 25. rujan 2006.)

11. Eurostat (2018). Culture statistics - cultural employment. ISSN 2443-8219. https://ec.europa.eu/eurostat/statistics-explained/index.php/Culture_statistics cultural_employment. (Pristupljeno: 21.travnja 2019.)

12. Hesmondhalgh, D. (2002). The Cultural Industries, London Thousand Oaks. New Delhi: Sage Publications.

13. KEA (2006). The Study on the Economy of Culture in Europe, Brussels: The European Commission, Directorate General for Education and Culture.

14. Krolo, K.; Tonković, Ž.; Vidović, D. i Žuvela, A. (2020). Utjecaj pandemije COVID-19 i zagrebačkog potresa na OCD-e u suvremenoj kulturi i umjetnosti. Rezultati testne faze istraživanja. Zagreb: Biblioteka 'Kultura nova'. https://kulturanova.hr/istrazivanje covid potres/izvjestaj/. (Pristupljeno 10.veljače 2021. godine)

15. McRobbie, A. (2002). From Holloway to Hollywood: Happiness at Work in the New Cultural Economy?, u: du Gay, P. and Pryke, M. (Eds.). Cultural Economy. Cultural Analysis and Commercial Life. London: Sage Publications.

16. Myerscough, J. (1988). The economic importance of the arts in Britain, London: Policy Studies Institute.

17. OECD (2020). Culture shock: COVID-19 and the cultural and creative sectors. http://www.oecd.org/coronavirus/policy-responses/culture-shock-covid-19-andthe-cultural-and-creative-sectors-08da9e0el. (Pristupljeno 10.veljače 2021.godine)

18. Polivtseva, E. (2020). Performing arts in times of the pandemic: status quo and the way forward. IETM REPORT. https://www.ietm.org/en/publications/performing-arts-in-times-of-the-pandemic-status-quo-and-the-way-forward. (Pristupljeno 10.veljače 2021.godine)

19. Primorac, J. (2010). Promjena strukture rada u kreativnoj ekonomiji: kultura, tranzicija $i$ kreativna klasa. Doktorska disertacija. Zagreb: Filozofski fakultet Sveučilišta u Zagrebu.

20. Primorac, J. (2021). Compendium of Cultural Policies and Trends in Europe, $21^{\text {st }}$ edition 2021. Country Profile: Croatia. Council of Europe/ERICarts: Available from World Wide Web: <http:// www.culturalpolicies.net>. 
21. Primorac, J. i Obuljen Koržinek, N. (2017). Compendium of Cultural Policies and Trends in Europe, 18th edition 2017. Country Profile: Croatia. Council of Europe/ERICarts: Available from World Wide Web: < http:// www.culturalpolicies.net>.

22. Primorac, J.; Barada, V. and Buršić, E. (2020). Creative Workers in Permanent Crisis: Labor in the Croatia's Contemporary Arts and Culture, u: Kiriya, I.; Kompatsiaris, P. and Mylonas, Y. (Eds.). The Industrialization of Creativity and Its Limits. Cham: Springer, 31-48. doi:10.1007/978-3-030-53164-5_3

23. Rašić Bakarić, I.; Bačić, K. i Božić, LJ. (2015). Mapiranje kreativnih i kulturnih industrija u Republici Hrvatskoj. Zagreb: Ekonomski institut.

24. Ross, A. (2008). The new geography of work: power to the precarious?. Theory, Culture and Society 25 (7-8): 31-49.

25. Stubbs, P. (2019). 'Paul Stubbs: Socijalna politika ne smije biti fokusirana na veterane'. Intervju, Portal Novosti, 07. listopada 2019. https://www.portalnovosti.com/paul-stubbs-socijalna-politika-ne-smije-biti-fokusirana-na-veterane. (Pristupljeno 20.8.2020.)

26. UNESCO (2013). Creative economy report. Widening local development pathways. 2013 special edition. Paris: UNESCO. http://www.unesco.org/culture/ pdf/creative-economy-report-2013.pdf. (Pristupljeno: 20.ožujka 2019.)

27. UNESCO (2020). Culture in Crisis. Policy Guide for a Resiliant Sector. Paris: UNESCO.

28. UNCTAD (2008). Creative Economy Report 2008. The Challenges of Assessing the Creative Economy: towards Informed Policy Making. http://www.unctad.org/en/ docs/ditc20082cer en.pdf. (Pristupljeno 12. veljače 2009.) 


\section{PRILOG}

Tablica 4.

Uzorak prema zemlji i dobi ispitanika/ica

\begin{tabular}{|c|c|c|c|c|c|c|c|}
\hline Država & & $18-30$ god. & $31-40$ god. & 41-50 god. & $51-60$ god. & $60+$ god. & Ukupno \\
\hline \multirow{3}{*}{ BA } & $N$ & 12 & 11 & 19 & 5 & 4 & 51 \\
\hline & $\%$ unutar zemlje & $23,50 \%$ & $21,60 \%$ & $37,30 \%$ & $9,80 \%$ & $7,80 \%$ & $100,00 \%$ \\
\hline & $\%$ unutar dobi & $19,00 \%$ & $5,70 \%$ & $10,90 \%$ & $6,00 \%$ & $12,90 \%$ & $9,40 \%$ \\
\hline \multirow{3}{*}{ HR } & $N$ & 5 & 44 & 32 & 21 & 8 & 110 \\
\hline & $\%$ unutar zemlje & $4,50 \%$ & $40,00 \%$ & $29,10 \%$ & $19,10 \%$ & $7,30 \%$ & $100,00 \%$ \\
\hline & $\%$ unutar dobi & $7,90 \%$ & $22,80 \%$ & $18,40 \%$ & $25,30 \%$ & $25,80 \%$ & $20,20 \%$ \\
\hline \multirow{3}{*}{ ME } & $N$ & 5 & 33 & 23 & 5 & 3 & 69 \\
\hline & $\%$ unutar zemlje & $7,20 \%$ & $47,80 \%$ & $33,30 \%$ & $7,20 \%$ & $4,30 \%$ & $100,00 \%$ \\
\hline & $\%$ unutar dobi & $7,90 \%$ & $17,10 \%$ & $13,20 \%$ & $6,00 \%$ & $9,70 \%$ & $12,70 \%$ \\
\hline \multirow{3}{*}{ MK } & $N$ & 5 & 19 & 24 & 7 & 0 & 55 \\
\hline & $\%$ unutar zemlje & $9,10 \%$ & $34,50 \%$ & $43,60 \%$ & $12,70 \%$ & $0,00 \%$ & $100,00 \%$ \\
\hline & $\%$ unutar dobi & $7,90 \%$ & $9,80 \%$ & $13,80 \%$ & $8,40 \%$ & $0,00 \%$ & $10,10 \%$ \\
\hline \multirow{3}{*}{ RS } & $N$ & 32 & 66 & 61 & 36 & 13 & 208 \\
\hline & $\%$ unutar zemlje & $15,40 \%$ & $31,70 \%$ & $29,30 \%$ & $17,30 \%$ & $6,30 \%$ & $100,00 \%$ \\
\hline & $\%$ unutar dobi & $50,80 \%$ & $34,20 \%$ & $35,10 \%$ & $43,40 \%$ & $41,90 \%$ & $38,20 \%$ \\
\hline \multirow{3}{*}{ SI } & $N$ & 4 & 20 & 15 & 9 & 3 & 51 \\
\hline & $\%$ unutar zemlje & $7,80 \%$ & $39,20 \%$ & $29,40 \%$ & $17,60 \%$ & $5,90 \%$ & $100,00 \%$ \\
\hline & $\%$ unutar dobi & $6,30 \%$ & $10,40 \%$ & $8,60 \%$ & $10,80 \%$ & $9,70 \%$ & $9,40 \%$ \\
\hline \multirow{3}{*}{ TOTAL } & $N$ & 63 & 193 & 174 & 83 & 31 & 544 \\
\hline & $\%$ unutar zemlje & $11,60 \%$ & $35,50 \%$ & $32,00 \%$ & $15,30 \%$ & $5,70 \%$ & $100,00 \%$ \\
\hline & $\%$ unutar uzorka & $100,00 \%$ & $100,00 \%$ & $100,00 \%$ & $100,00 \%$ & $100,00 \%$ & $100,00 \%$ \\
\hline
\end{tabular}


Tablica 5.

Uzorak prema zemlji i obrazovanju ispitanika/ica

\begin{tabular}{|c|c|c|c|c|c|c|}
\hline Država & & $\begin{array}{c}\text { Srednja } \\
\text { škola/ } \\
\text { Gimnazija }\end{array}$ & BA & MA/MSc & $\begin{array}{c}\text { Magisterij* / } \\
\text { Doktorat }\end{array}$ & Ukupno \\
\hline \multirow{3}{*}{ BA } & $N$ & 6 & 24 & 12 & 9 & 51 \\
\hline & $\%$ unutar zemlje & $11,80 \%$ & $47,10 \%$ & $23,50 \%$ & $17,60 \%$ & $100,00 \%$ \\
\hline & $\%$ unutar obrazovanja & $9,80 \%$ & $9,30 \%$ & $11,40 \%$ & $7,60 \%$ & $9,40 \%$ \\
\hline \multirow{3}{*}{$H R$} & $\mathrm{~N}$ & 18 & 56 & 23 & 13 & 110 \\
\hline & $\%$ unutar zemlje & $16,40 \%$ & $50,90 \%$ & $20,90 \%$ & $11,80 \%$ & $100,00 \%$ \\
\hline & $\%$ unutar obrazovanja & $29,50 \%$ & $21,70 \%$ & $21,90 \%$ & $10,90 \%$ & $20,20 \%$ \\
\hline \multirow{3}{*}{ ME } & $\mathrm{N}$ & 2 & 43 & 12 & 12 & 69 \\
\hline & $\%$ unutar zemlje & $2,90 \%$ & $62,30 \%$ & $17,40 \%$ & $17,40 \%$ & $100,00 \%$ \\
\hline & $\%$ unutar obrazovanja & $3,30 \%$ & $16,70 \%$ & $11,40 \%$ & $10,10 \%$ & $12,70 \%$ \\
\hline \multirow{3}{*}{ MK } & $N$ & 6 & 25 & 4 & 20 & 55 \\
\hline & $\%$ unutar zemlje & $10,90 \%$ & $45,50 \%$ & $7,30 \%$ & $36,40 \%$ & $100,00 \%$ \\
\hline & $\%$ unutar obrazovanja & $9,80 \%$ & $9,70 \%$ & $3,80 \%$ & $16,80 \%$ & $10,10 \%$ \\
\hline \multirow{3}{*}{ RS } & $\mathrm{N}$ & 22 & 89 & 42 & 55 & 208 \\
\hline & $\%$ unutar zemlje & $10,60 \%$ & $42,80 \%$ & $20,20 \%$ & $26,40 \%$ & $100,00 \%$ \\
\hline & $\%$ unutar obrazovanja & $36,10 \%$ & $34,50 \%$ & $40,00 \%$ & $46,20 \%$ & $38,20 \%$ \\
\hline \multirow{3}{*}{ SI } & $N$ & 6 & 21 & 12 & 10 & 49 \\
\hline & $\%$ unutar zemlje & $13,70 \%$ & $41,20 \%$ & $23,50 \%$ & $19,60 \%$ & $100,00 \%$ \\
\hline & $\%$ unutar obrazovanja & $11,50 \%$ & $8,10 \%$ & $11,40 \%$ & $8,40 \%$ & $9,40 \%$ \\
\hline \multirow{3}{*}{ TOTAL } & N & 60 & 258 & 105 & 119 & $542^{* *}$ \\
\hline & $\%$ unutar zemlje & $11,20 \%$ & $47,40 \%$ & $19,30 \%$ & $21,90 \%$ & $100,00 \%$ \\
\hline & $\%$ unutar uzorka & $100,00 \%$ & $100,00 \%$ & $100,00 \%$ & $100,00 \%$ & $100,00 \%$ \\
\hline
\end{tabular}

*Magisterij prema predbolonjskom programu ${ }^{* *}$ Dva missing odgovora u uzorku. 


\title{
Lost Income and Found Solidarities: The Impact of the First Wave of the
} COVID-19 Pandemic on the Cultural Sector in South-Eastern Europe

\author{
Jaka Primorac \\ Institute for Development and International Relations, Zagreb, Croatia \\ e-mail: jaka@irmo.hr
}

\begin{abstract}
The paper presents results of a research on the impact of the first wave of the COVID-19 pandemic on the life and work of cultural workers in South-Eastern Europe, which was carried out from May till July 2020. The paper shows how in that period in all of the researched countries (Bosnia and Herzegovina, Croatia, Northern Macedonia, Montenegro, Serbia and Slovenia) cultural workers noted a significant drop of income, expected decrease in total earnings and continued trend of the necessity of additional work and self-exploiting practices. In the researched countries, the measures for minimizing the negative impact of the pandemic on the cultural sector were mainly not adopted at the local level. If they were adopted on the national level, these predominantly included one-time assistance to artists and cultural workers, and selected indirect measures, where a difference between EU Member States and those outside of the EU exists. The data shows a limited influence of international foundations and networks on the sector, however, one can note an increase of initiatives and networks of solidarity of professional associations, NGOs and independent cultural workers. The research shows that for the cultural sector in South-Eastern Europe the first wave of the COVID-19 pandemic has brought about a number of negative consequences, while the early measures in most of the countries were of limited impact and scope. The positive effects are reflected in the strengthening of solidarity within the sector and greater networking among cultural workers, as well as in the strengthening of the view that a new, more sustainable approach to the cultural sector is needed, and which is not based on the market logic.
\end{abstract}

Key words: cultural sector, COVID-19, pandemic, cultural work, project work, cultural policies, South-Eastern Europe, resilience. 